\title{
The sustainability of public transport operation based on financial point of view
}

\author{
Arif Budiarto ${ }^{1, *}$ \\ ${ }^{1}$ Civil Engineering Department, University of Sebelas Maret, Surakarta, Indonesia
}

\begin{abstract}
One of the keys to be successful in transport modeling is indicated by how large the transfence of private users to public transports. The public transport role to solve the problem of traffic jam in urban areas is indisputable. It is undeniable that public transport is a very efficient mode in using road space. For that reason, the sustainability of public transport becomes a necessity that must be achieved. When there is no possible way to minimize the operating cost, the only way is by raising the revenue. The revenue really depends on the number of passengers and not by raising fare, as the fare has been set by the government. This paper attempts to analyze the financial resilience on public transport in Surakarta City i.e. Batik Solo Trans (BST) based on the data of users demand on public transport. This study found that the total of real passengers per year was very few that there were only 87,908 passengers and the financial loss related to the BST operation was Rp. 291,302,006.00 per year. If it happens continuesly, the sustainability is difficult to maintain, unless the Surakarta Municipal Government is willing to cover the loss. The operation of BST will reach break even point if the number of passengers reach 161,056 people per year.
\end{abstract}

\section{Introduction}

According to the Law No. 22 of 2009 [1], the Government is responsible to the provision of public transport, to meet community's needs for urban transport and to solve congestion problems in urban areas. In his study in Surabaya [2], Tahir concluded that the causes of traffic congestion in the city were due to the low use of public transport, which was $2.64 \%$ and the height private car usage $(82.83 \%)$. Public transport is a highly efficient mode for the use of road spaces. For that reason, maximizing the use of public transport becomes a very important solution to solve the transport problem.

There are many factors that influence the people to choose transport mode to go to their daily activities places. From travelers' point of view, transport modes that have high utility are considered from the quantitative point of view (i.e. low cost and low travel time) and qualitative point of view (i.e. convenient, flexible, reliable, and safe). Actually there are no modes that have aforementioned attributes. Private car is low travel time, convenient, flexible, reliable and safe, but it costs more. In the other hand, public transport mode is low-cost but it tends to be inconvenient, less flexible and less reliable, longer travel time and low safety.

Public transport is one of the inferior modes, which will be left by the users when their income level increases. For this reason, when the economical level of the people in urban area increases, the mode of public transport tends to be not prioritized and people prefer to use private cars [3]. AS a result, tremendous traffic jams which occure in metropolitan and megapolitan cities, and public transport becomes one of the best solutions. It becomes necessity to change from private car to public transport.

In order that private car users move to public transport, the public transport must be comfortable and short in travel time. It takes government policy as transport stakeholder to provide special lane and set signal priority at each intersection of public transport to shorter travel time. In order that the public transport can provide a comfortable and reliable service, then it must be financially reliable. If the operation of public transport from a financial point of view is not reliable, it is not easy to make public transport convenient and reliable.

This paper attempts to analyze the financial resilience of public transport operators in the city of Surakarta based on the data of users' demand on public transport. In addition, this paper purpose is to know how big the limitation of the demand to get the break even point of public transport, and to find the solution of surviving as there are only few passengers.

* Corresponding author: abudiarto83@gmail.com 


\section{The role of public transport in reducing traffic congestion}

The public transport is a system of transferring people and / or goods from one place to another by using motor vehicles which is provided for people who bear the fare [4]. Meanwhile, according to [5] public transport is a mode of transport for transferring persons and / or goods from one place to another by means of a vehicle. While according to [6], urban transport is a means of urban passenger transport which normally runs on the highway in mixed traffic conditions provided by private or public carriers and it is in certain groups and routes. From several definitions as mentioned above, it can be concluded that public transport is not only used for humans but also for goods.

The existence of public transport is very needed by people, especially for the community groups who cannot facilitate their movement by private transport mode. While public transport of goods, its existence is needed by all people although they have private transports, because everyone will need goods for the fulfilment of everyday life. Therefore, in Law No. 22 of 2009 Article 139 is confirmed that the government must guarantee the availability of public transport for humans or/ and goods for inter-city movement among provinces, as well as across national borders [1]

Due to the absence of regulation of vehicle ownership restrictions for the community, traffic in urban areas grows so fast. Within five years [7], vehicles in Jakarta grew $7.93 \%$ in average per year as shown in Table 1. While length of road as shown in Table 2 only grew $0.33 \%$ per year [8]. From these data it can be concluded that the congestion is unlikely to be resolved, even it will be worse if the government as a stakeholder of transport let vehicle ownership grow without restrictions.

Table 1. Number of vehicles in Jakarta.

\begin{tabular}{|c|c|c|c|c|c|}
\hline \multicolumn{5}{|c|}{ Number of Vehicles (in million) } & \multirow{2}{*}{$\begin{array}{c}\text { Average Growts } \\
(\%)\end{array}$} \\
\hline 2010 & 2011 & 2012 & 2013 & 2014 & \\
\hline 7,3 & 8 & 8,5 & 9,3 & 9,9 & 7,93 \\
\hline
\end{tabular}

Source [6]

The main problem of urban transport is traffic congestion that impacts on increasing air pollution and fuel consumption. This requires a comprehensive and multifaceted studies. Whereas, what seems apparent in sight is the occurrence of waste of road space as a result of excessive use of private cars. The actual essence of transport is the movement of people and goods from one place to another, and not the movement of the vehicles. As a matter of fact, traffic congestion gets worse because every economically capable person wants to facilitate himself to move using private cars.

Table 2. Length of road by type in Jakarta.

\begin{tabular}{|c|c|c|c|c|c|c|c|}
\hline \multirow[b]{2}{*}{ Year } & \multicolumn{6}{|c|}{ Type of Road } & \multirow[b]{2}{*}{ Amount } \\
\hline & Tol & $\begin{array}{c}\text { Primary } \\
\text { Artery }\end{array}$ & $\begin{array}{l}\text { Primary } \\
\text { Collector }\end{array}$ & $\begin{array}{c}\text { Secondary } \\
\text { Artery }\end{array}$ & $\begin{array}{l}\text { Secondary } \\
\text { Collector }\end{array}$ & $\begin{array}{l}\text { Admin. } \\
\text { City }\end{array}$ & \\
\hline (1) & (2) & (3) & (4) & (5) & (6) & (7) & (8) \\
\hline 2010 & $123,481.00$ & $123,653.00$ & $18,994.00$ & $563,438.00$ & $997,019.87$ & $5,039,454.16$ & $6,866,040.84$ \\
\hline 2011 & $123,481.00$ & $123,653.00$ & $18,994.00$ & $563,438.00$ & $1,057,666.87$ & $5,045,059.16$ & $6,932,294.84$ \\
\hline 2012 & $123,731.00$ & $128,882.50$ & $23,694.00$ & $535,256.69$ & $1,027,019.87$ & $5,117,258.20$ & $6,955,842.26$ \\
\hline 2013 & $123,731.00$ & $128,882.50$ & $23,694.00$ & $535,256.69$ & $1,027,019.87$ & $5,117,258.20$ & $6,955,842.26$ \\
\hline 2014 & $123,731.00$ & $128,882.50$ & $23,694.00$ & $535,256.69$ & $1,027,019.87$ & $5,117,258.20$ & $6,955,842.26$ \\
\hline
\end{tabular}

Source [7]

\section{Sustainability of public transport}

Today's transport has become a primary necessity for every human life. Every day millions of people move from place to place and millions of tons of goods move from production centers to the consumers endlessly. All happen in order to meet the needs of human life, which cannot be fulfilled in the place where they live.

The movement of vehicles as a representation of the movement of people and goods, it is getting greater to its number resulting to new problems in the form of traffic congestion. The traffic congestion is one of many disadvantages of transport activity which will lead to waste energy and time and decrease road user productivity as well. Another negative impact of traffic congestion is the occurrence of stress of road users and will increase environmental pollution that endangers public health. In order that transport activities not to cause a negative impact on human life, a new breakthrough in the form of sustainable transport system is needed. A sustainable transport system is a transport system that does not create negative impacts that the next generation cannot anticipate [9].

Traffic congestion is a serious issue that occupies urgent priority in finding its solution. The strategy for handling traffic congestion in principle is divided into three levels, namely macro level i.e. spatial, mezzo in the form of transport demand management (TDM), and at the micro level of street level [10]. Since cities in Indonesia are generally a sprawl-spreading old city [11], which is not designed as a compact city, therefore handling of traffic congestion at the macro level is very difficult. One solution that can still be strived is by 
maximizing the use of mass public transport that constitutes one of the strategies of handling traffic congestion at mezzo level.

As mentioned above, one concrete policy to motivate the use of public transport is to improve the mass public transport services in order to approach the attributes of private transport. Private car users are much more attracted to switch to public transport when the attributes of mass transport services which are regarded as important factors such as the decreasing of travel time, the increasing of comfort and reliability and affordable rates are considered sufficient. Fare attributes are taken into account because the paradigm of private transport in Indonesia is not only private cars, but also motorcycles which are considered as inferior modes. One of the strategies to increase public transport market that is studied in the Surakarta area is quite effective, that is by reducing the cost and travel times of public transport at once. In extreme conditions, the market share of public transport will rise from $11.928 \%$ to $41 \%$, against the three modes of competitors i.e. private cars, motorcycles, and bicycles [12].

It shows how important the role of public transport in overcoming the problem of traffic congestion. Hence, it is very important to maintain the quality of public transport services for its sustainability. The important thing that can make the operation of public transport remains sustainable is the issue of financial reliability. Financial reliability occurs when in the operation of public transport has profits.

\section{Public transport management}

Managing public transport is the same as managing a company, which must be managed well by implementing management functions. Management is an attempt to achieve the goal by planning an activity well, organizing, implementing, and supervising [13]. While the main function in a management is a matter of finance, personnel, marketing, and production. Management of a transport service business is an Operations-Production management type. Operations-Production Management has repetitive properties, and its activity is usually permanent or may be semi-permanent to produce a product or service [14]. The product or service is produced for the purpose of obtaining profit.

\subsection{The concept of loss and profit}

Every business does not always make a profit, sometimes it also suffers a loss. If the cost burden is greater than the income, the difference is called loss. Profit or loss is the result of periodic calculations, which have not reflected actual profit or loss. Actual profit or loss can be recognized only if the company has terminated its activities and been liquidated [15].

Meanwhile [16] profit defines as an increase of economic benefits during an accounting period, such as an increase in assets or a decrease in liabilities, resulting in an increase in equity, except those involving transactions with shareholders. Whereas according to
[17] profit or loss is the income deducted by all expenses incurred. A business that does not earn a profit in its business will go bankrupt and will not be sustainable. Similarly, in the management of public transport, the operation of public transport will be more sustainable when the profit gained is higher.

\subsection{Concept of cost}

According to [18] costs are outflows or use of assets or the debt, or a combination of both, during a period derived from the sale of a production or service. While [19] defines that cost is a decline in economic benefits during an accounting period in the form of outflow or decrease in assets or occurrence of liabilities resulting in a decrease of equity that is not disbursed to investors. KAM [20] defines costs as impairment of assets or increase in debt or increase in shareholder equity (stockholder's equity) as a result of the use of goods and services by a business unit to generate income in the current period.

Regardless of the difference in definition, basically the cost has a similarity that is economic sacrifice measured by the value of the currency to acquire goods or services or to generate income. For planning and cost control purposes, as well as decision making, costs can be grouped into three types i.e. fixed costs, variable costs, and semi variable costs [21]. Fixed cost is a fixed total cost, not affected by changes in activity volume, but if sales volume increases then unit cost will become smaller and vice versa.

The variable cost is the cost of which the amount is proportional to the volume of activity changes. However, unit costs are not influenced by the volume of activity or sales. While the semi-variable cost is the cost between fixed and variable, the total amount will change according to the volume change of activity, but the nature of the change is not proportional. At semivariable costs, unit costs will change inversely related to changes in activity volume but incomparable.

The classification of costs on the basis of the tendency of changes to certain activities as mentioned above is very important in the process of profit planning or break even analysis. According to [22] in relation to cost planning and supervision, fixed costs are divided into two types: Committed fixed cost and Discretionary fixed costs.

\subsection{Concept of revenue}

Revenue is the amount of money coming into cash as a result of the sale of production goods or services provided to consumers. In the management of public transport, the only source of revenue is the sale of tickets to passengers in accordance with the amount of fare set by the government as a stakeholder. The more the number of passengers, the higher the revenue will be 


\section{Research methodology}

This research have developed by primary data through direct observation of BST operation in field. The surveyors recorded the number of pasangers of BST who got on the bus and got off the bus at each bus stop. It is done for two opposite directions from apple to apple. This data describes the total income of the operation of the BST which is the only entry point. While the cost data used to operate BST were obtained from the management as secondary data.

Cost data involve fix cost and variable cost. The fixed data consist of vehicle tax, vehicle charge, vehicle depreciation cost, capital interest cost, insurance fee, rental fees for offices and garages, electricity, water and telephone costs, and employee charges. While the variable cost record from management office of BST includes fuel, engine oil, axle oil, transmission oil, greese, brake fluid, oil filter, air filter, engine overhaul, overhaul body, body maintenance, replacement parts, tire replacement, vehicle crew, ect. Others data that neccessary to this analisys are take from internet, government office of Surakarta City, and ect. Based on the above data, the financial feasibility calculation of BST operation is done.

\section{Case study of financial feasibility of public transport in Surakarta}

In accordance to the spirit of the Law no. 22 of 2009 concerning road transport traffic [1], the government is responsible to manage of public transport. Public transport is organized by the government as a stakeholder with the primary objective is to meet the needs of the movement of the people by sticking to the overall principle of traffic flow. In the implementation of public transport, the government as a stakeholder should prepare a strategic plan as a public transport master plan that will produce a public transport routing system. Afterwards, the government prepares operational plans, either independently or by involving the private sector based on the minimum service standard that has been established. Furthermore, the implementation of public transport operations can be submitted to the private sector through a bidding system, and the government as a stakeholder conducts monitoring and evaluation of its implementation.

In the past, the implementation of urban public transport was not carried out by the mechanism mentioned above. In Bandung city, in determining the route, the government still uses the 'approx' method [24]. The mechanisms of public transport that have seemed to come initiatively from a 'group of people' that offers public transport management with their own operational planning concepts: route path, mode type, and so on. To be more convincing, a group of people are on behalf of a cooperative. This mechanism is very similar to what happened in Surakarta. A group of people formed a cooperative, made a route track and then applied for permission for route and applied credit to the leasing agency to get the vehicle, and finally ran a public transport service business. The type of vehicle used was a small minibus, commonly referred as 'Angkot'.

On September 1, 2010, the Government of Surakarta City launched Batik Solo Trans (BST), which became a pioneer of Bus Rapid Transit (BRT) system in Surakarta City [20] meanwhile routes of Angkot were to be maintained. The Operation of BST was one form of policy from the central government related to the operation of the transit system in Indonesia. Batik SoloTrans Bus operation was done by the government of Surakarta as the regulator while Perum DAMRI was as the operator. Batik Solo Trans Bus was operated in order that mass public transport in Surakarta City were available to serve the needs of internal and external movement of the community in Surakarta City. Since February 25, 2014 BST, which once had two corridors only then it increased to 8 corridors.

This paper presents a discussion of the financial feasibility of BST operations, through the BST corridor 1 as a sample, with routes: Palur -Pasar Gede - Gladak Kustati - Tipes - Bayangkara - Baron - Gendengan Purwosari - Kleco - Pabelan - Kartosuro- Terminal Adisumarmo Airport. Operation data can be seen in Table 3. While the data on the number of passengers using, it can be seen in Table 4, which is the number of accumulated passengers that rose from the origin of destination, with the same fare for all distances.

Table 3. Operational data of BST corridor 1.

\begin{tabular}{|l|c|c|}
\hline Operational Data & Unit & Quantity \\
\hline Route Ditance & $\mathrm{km}$ & 22 \\
Number of Bus & bus & 14 \\
Average Headway & minute & 12 \\
Bus Capacity & passanger & 45 \\
Number of Trip/day & trip/days & 4 \\
Cycle Time & minute & 190 \\
\hline
\end{tabular}

(source: survey data)

The revenues from BST operating services are entirely sourced from ticket sales to passengers. The rate is determined by the Surakarta City Government, at a rate of Rp.4,500.00 for public passengers and Rp. $2,000.00$ for student passengers. To calculate the revenues, it is assumed that all of passenger on holidays are public passengers. While on work days it is assumed that passenger proportion is $25 \%$ of student passengers and $75 \%$ are public passengers. Actual revenues of operation can be seen on Table 5 . 
Table 4. Passanger data of BST corridor 1.

\begin{tabular}{|c|l|c|c|c|}
\hline \multirow{2}{*}{$\begin{array}{c}\text { Type of } \\
\text { Days }\end{array}$} & \multirow{2}{*}{ Time } & \multicolumn{3}{|c|}{$\begin{array}{c}\text { Number of passenger by Type of } \\
\text { travel }\end{array}$} \\
\cline { 3 - 5 } & & Inbound & Outbound & Round trip \\
\hline \multirow{5}{*}{ Free Day } & morning & 18 & 28 & 46 \\
& noon & 41 & 27 & 68 \\
& afternoon & 39 & 19 & 58 \\
\cline { 2 - 5 } & Average & 33 & 25 & 58 \\
& Per day & 132 & 100 & 234 \\
\hline \multirow{4}{*}{ Work } & morning & 26 & 27 & 53 \\
day & noon & 41 & 34 & 75 \\
& afternoon & 26 & 27 & 53 \\
\cline { 2 - 5 } & Average & 31 & 30 & 61 \\
& Per day & 124 & 120 & 244 \\
\hline
\end{tabular}

(source: survey data)

Table 5. Actual revenue of BST operation.

\begin{tabular}{|c|c|c|c|c|c|c|c|c|}
\hline \multirow{2}{*}{ Time } & \multirow{2}{*}{ Trip } & \multicolumn{5}{|c|}{ Passenger Number } & \multirow{2}{*}{$\begin{array}{l}\text { Base } \\
\text { Fare }\end{array}$} & \multirow{2}{*}{$\begin{array}{c}\text { Revenue } \\
\text { (Rp) }\end{array}$} \\
\hline & & $\begin{array}{l}\text { per } \\
\text { trip }\end{array}$ & Daily & Annually & Total & $\%$ & & \\
\hline \multirow{2}{*}{ Holidays } & inbound & 33 & 132 & 12,672 & \multirow{2}{*}{22,272} & \multirow{2}{*}{100} & \multirow{2}{*}{$4,500.00$} & \multirow{2}{*}{$100,224,000.00$} \\
\hline & outbound & 25 & 100 & 9,600 & & & & \\
\hline \multirow{2}{*}{$\begin{array}{l}\text { Work- } \\
\text { days }\end{array}$} & inbound & 31 & 124 & 33,356 & \multirow{2}{*}{65,636} & 25 & $2,000.00$ & $32,818,000.00$ \\
\hline & outbound & 30 & 120 & 32,280 & & 75 & $4,500.00$ & $221,521,500.00$ \\
\hline & & & & Total & 87,908 & & & $54,563,500.00$ \\
\hline
\end{tabular}

Costs calculated on the operation of BST are fixed costs and variable costs. The item of fixed cost as shown as Table 6, while the variable cost consist of Fuel, Engine Oil, Axle Oil, Transmission Oil, Grease , Brake Oil, Oil Filter, Air Filter, Engine Overhaul, Body Overhaul, Body Maintenance, Spare part, Tire, Terminal Tax, and Employee Salary. There are three scenario of fixed cost, while the variable cost are the same for all scenario. The first scenario is assumed that the bus is purchased through a leasing system with a tenor of 6 years and a fleet depreciation for 15 years. The second scenario is assumed that the bus is a grant from the central government, the operator does not have to pay interest and instalment of principal loan. And the last scenario is assumed that the bus is a grant from the central government, the operator does not have to pay interest and instalment of principal loan, and the depreciation is not calculated.

Table 6. Calculation of fixed cost.

\begin{tabular}{|c|c|c|c|}
\hline Description & Scenario 1 & Scenario 2 & Scenario 3 \\
\hline Vehicle Tax & $5,200,000.00$ & $5,200,000.00$ & $5,200,000.00$ \\
Depreciation & $78,500,000.00$ & $78,500,000.00$ & 0 \\
Interest of Loan & $179,866,667.00$ & 0 & 0 \\
Opportunity of DP & $45,600,000.00$ & $45,600,000.00$ & $45,600,000.00$ \\
Jasa Raharja Insurance & $14,250,000.00$ & $14,250,000.00$ & $14,250,000.00$ \\
TLO Insurance & $9,500,000.00$ & $9,500,000.00$ & $9,500,000.00$ \\
Office and Garage Rent & $14,285,715.00$ & $14,285,715.00$ & $14,285,715.00$ \\
Phone, Electrical, Water & $4,285,715.00$ & $4,285,715.00$ & $4,285,715.00$ \\
Employee Salary & $7,714,285.00$ & $7,714,285.00$ & $7,714,285.00$ \\
\hline Total & $59,202,382.00$ & $179,335,715.00$ & $100,835,715.00$ \\
\hline
\end{tabular}

Table 7 shows the results of profit calculations from the operation of BST. For all of scenarios, the profit is negative or in other words there is a loss in the operation of BST. Increasing bus revenue will make bus operation not suffer a loss. The only one possibility to do is by increasing the number of passengers as the example. Here is a simulation to calculate the number of passengers needed by BST to get a break even point in its operation. From this simulation, it takes an additional number of passengers in each scenario about 357 people / days or 45 people / trips, 132 people / days or 17 people / trips, and 36 people / days or 5 people / trip. of passengers as shown as Table 8. 
Table 7. Profit based on actual number of passanger (Rp.).

\begin{tabular}{|c|c|c|c|}
\hline Description & Scenario 1 & Scenario 2 & Scenario 3 \\
\hline Fixed Cost & $359,202,382.00$ & $179,335,715.00$ & $100,835,715.00$ \\
\hline Variable Cost & $286,663,124.00$ & $286,663,124.00$ & $286,663,124.00$ \\
\hline Total Cost & $645,865,506.00$ & $465,998,839.00$ & $387,498,839.00$ \\
\hline Revenue & $354,563,500.00$ & $354,563,500.00$ & $354,563,500.00$ \\
\hline Profit & $\mathbf{( 2 9 1 , 3 0 2 , 0 0 6 . 0 0 )}$ & $\mathbf{( 1 1 1 , 4 3 5 , 3 3 9 . 0 0 )}$ & $\mathbf{( 3 2 , 9 3 5 , 3 3 9 . 0 0 )}$ \\
\hline
\end{tabular}

Table 8. The simulation of passengers number achieving break even point.

\begin{tabular}{|c|c|c|c|}
\hline Description & Scenario 1 & Scenario 2 & Scenario 3 \\
\hline \multicolumn{4}{|c|}{ Cost Calculation (Rp) } \\
\hline Fixed Cost & $359,202,382.00$ & $179,335,715.00$ & $100,835,715.00$ \\
\hline Variable Cost & $286,663,124.00$ & $286,663,124.00$ & $286,663,124.00$ \\
\hline Total Cost & $645,865,506.00$ & $465,998,839.00$ & $387,498,839.00$ \\
\hline \multicolumn{4}{|c|}{ Pasanger Calculation } \\
\hline Actual/day & 476.00 & 476.00 & 476.00 \\
\hline Expected/day & 833.00 & 608.00 & 512.00 \\
\hline Addition/day & 357.00 & 132.00 & 36.00 \\
\hline Addition/year & $161,055.00$ & $116,021.00$ & $96,316.00$ \\
\hline Addition (\%) & 75 & 28 & 8 \\
\hline Revenue (Rp.) & $645,865,506.48$ & $465,998,839.21$ & $387,498,838.84$ \\
\hline Profit (Rp.) & 0.00 & 0.00 & 0.00 \\
\hline
\end{tabular}

\section{Conclusion}

The operation of BST in Surakarta city is still less desired by the community [25]. This is evidenced by the low number of passengers based on primary survey data on this study. This study found that the number of real passengers per year was only 87,908 people, so the operation of BST still suffers losses. The sustainability of BST is difficult to maintain, unless the Surakarta Municipal Government is willing to cover the loss.

In order that the operation of BST can be maintained, the best solution is to increase the number of passengers and not by eliminating depreciation expenses or expecting subsidies from the central government only. It takes government policy to motivate private car users to move to public transport.

In the future, it requires a study to find out what factors make people prefer to facilitate their movement by using private cars or motorcycles. This study will find variations of parameter values of each attribute that influence people choosing private cars and motorcycles. By performing the sensitivity test of the all parameters obtained, it will be known which attributes are sensitive that affect the perception of private car users and motorcycle users to switch to public transport mode. Furthermore, concrete actions by the government as public transport stakeholders are necessary to follow up on this research.

\section{References}

1. Law of the Republic of Indonesia No. 22, on Traffic and Road Transport., (2009)

2. A. Tahir, Mass Transport as an Alternative to Overcome the Problem of traffic congestion in Surabaya, Jurnal SMARTek, August, Vol. 3, No. 3, pp. 169 - 182. (2005)

3. A.K. Islam, Analysis of Vehicle Selection Determinants for Employees in Makassar City, Thesis S1 University of Hasanuddin Makasar, (2013)

4. Government Regulation of The Republic of Indonesia No. 41 about transport roads (1993)

5. Minister of Transport Decree No. KM.35 on the Implementation of Public Transport on Public Roads (2003)

6. V.R. Vuchic, Urban Public Transport : System and Technology, Prentice Hall.Inc, New Jersey (1981)

7. https://databoks.katadata.co.id/datapublish/2016/08/0 4/jumlah-kendaraan-bermotor-di-jakarta-2010-2014

8. Central Statistics Agency of DKI Jakarta, Transport Statistics of DKI Jakarta, (2015)

9. H.W. Richardson, Cang-He C. Bae , M. Baxamusa, Compact Cities in Developing Countries : Assesment and Implications. Dalam Mike Jenks \& Rod Burgess (Eds) Compact Cities : Sustainable Urban Forms for Developing Countries. London : Spon Press. (2000)

\footnotetext{
* Corresponding author: abudiarto83@gmail.com
} 
10. Dittmar, Hank, And Ohland, Gloria, The New Transit Town: Best Practice in Transit-Oriented Development, Island Press, Washington (2004)

11. M.Z. Mahriyar, J.H. Rho, The Compact City Concept in Creating Resilient City and Transport System in Surabaya, Procedia - Social and Behavioral Sciences 135, $41-49$, (2014)

12. A. Budiarto, A. Syafruddin, I. Santoso , H.A.S. Lubis, Strategy of Increasing Public Transport Market Share in Surakarta City, Jurnal Transportasi, December 3, Vol. 10, 225-234 (2010)

13. F.W. Taylor, The Principles of Scientific Management, Casimo Inc. , New York (2006)

14. P.C. Dinsmore and T.J. C. Davies, The right projects done right! John Wiley and Sons, ISBN 0-78797113-8. p.35 and further (2005)

15. Soemarso, Accounting An Introduction. Issue 5. The sixth edition Jakarta: Rineka Cipta (2010)

16. W.T. Harrison Jr., C.T. Horngren., C.W. Thomas, T. Suwardy. Financial Accounting (IFRS Edition), Issue 8, Vol. 1. Jakarta: Erlangga (2012)

17. Kuswadi, Increase Profit Through Financial Accounting Approach and Cost Accounting. Jakarta: PT. Elex Media Komputindo (2005)

18. Financial Accounting Standards Board (FASB).. "Statement of Financial Accounting Concepts No.2: Qualitative Characteristics of Accounting Information". Stamford. Connecticut (1980)

19. IAI, Financial Accounting Standards, Salemba Empat: Jakarta (1994)

20. Kam, Vernon, Accounting Theory, 2nd edition, New York, John Wiley \& Sion, inc. (1990)

21. Supriyono, Cost Accounting : cost collection and cost determination, Yogyakarta, BPFE UGM. Issue 2. To XII Print (1999)

22. Mulyadi, Total Quality Management: Paradigm Shift In Corporate Management, In Accounting Journal, Februari, Yogyakarta, STIE YKPN (1999)

23. Purnawan, Study planning of public transport transport in bandung city, Thesis Magister ITB, (1995)

24. http://tentangsolo.web.id/transportasi/batik-solotrans-bst (accessed on $26^{\text {th }}$ of July, 2018)

25. N.P. Rahma, P. D. Sasongko, Ismiyati, W. Kushardjoko, Evaluation of Batik Solo Trans Performance (case study: corridor 1 Kartasura-Palur, Surakarta), https://ejournal3.undip.ac.id/index.php/jkts/article/do wnload/3951/3850 (accessed on $20^{\text {th }}$ of July, 2018) 